\title{
SOLIDARITEIT OF/EN ANTITESE AS UITGANGSPUNT VIR DIE VERHOUDING VAN KERK EN WERELD
}

Einde van corpus Christianum.

Die lewe van die volkere van die Westerse wêreld het baie eeue op stewige grondslag gestaan. Hierdie grondslag sou ons Christelik kon noem. In die Middeleeue was daar 'n deur en deur kerklik-religieuse gefundeerde gesagskultuur. Die samelewing in al sy verbande en vertakkinge: gesin, kerk en staat, wetenskap en kuns, sosiale, politieke en ekonomiese verhoudinge, ja álles was min of meer Christelik en selfs kerklik gestempel. Vanaf die Renaissance en dic Aufklärung het hierin 'n verandering gekom. Die sogenaamde „corpus Christianum” het geleidelik ontbind. Die intieme betrekking tussen de samelewingsverbande en die kerklike altaar is verbreek, en in die plek van die vroeëre religieus en kerklik georiënteerde integrasie het 'n desintegrasieproses getree. Die resultaat van hierdie voltooide proses heet in dic reel sekularisasie. Hoewel daar heslis nog 'n sekere morele kode in die samelewing te bespeur is wat die gedrag van indiwidue en instellinge hepaal, is dit losgemaak van sy Middeleeuse teologies-Christelik hepaalde ondergrond.

In die Middeleeue was die ganse samelewing, in al sy skakeringe van politiek en onderwys, van kuns en wetenskap, van kultuur en beskawing bepaal deur sy betrokkenheid op die kerk. Dit was die Middeleeuse kerk se grootse sintese-ideaal, die magtige „eksperiment” om die antitese tussen kerk en wêreld op te los.

Die sintese-ideaal het die skolastiese visie op natuur en genade ten grondslag. Aangesien die kerk in die sfeer staan van die genade, of die bonatuurlike, en beskik oor die leiding en gesag ten aansien van alle sake van leer en lewe, dogmata et mores, moet die staat en die res van die samelewing - wat tot die natuurlike terrein hehoort - hulle in gehoorsaamheid buig voor die kerklike gesag.

Ek gaan nie in op die resultate (positief en negatief) wat die corpus Christianum vanaf die Middeleeue gehad het nie. Daar is beslis voordele maar ook baie nadele te noem van hierdie Middeleeuse ekspe. riment in sake die verhouding tussen kerk en wêreld. Dit bespreek ek egter nie verder nie.

Ons bepaal ons by die feit dat die corpus Christianum vanaf die vorige eeu al en veral in hierdie ceu met sy katastrofale geleurtenisse begin ontbind het. Die proses is al baie ver gevorder. 
In Wes-Europa is dit al byna voltooi terwyl in 'n land soos Suid. Afrika die proses ook reeds aan die gang is.

In die verband moet ek wys op die hand oor hand toenemende sekularisme.

\section{Sekularisme.}

Daaronder verstaan ek die proses binne ons Wes-Europese kultuur wat 'n tersydestelling van die Christelike norme vir die openbare lewe leteken. Die begrip hou dus 'n Christelike waarderingsoordeel in wat berus op die erkenning van die geopenbaarde wil van God waaraan die aardelewe onderworpe is. Of, soos Schippers dit stel: dit is 'n manier van lewe of 'n lewensbeskouing, wat alleen uitgaan van die geskape dinge en wat God nie wesenlik belangrik ag vir die lewe of denke van die mens nie. Dit wil sê dat die mens van hierdie wêreld homself toegesluit het vir en afgesluit het van die kragte van die toekomende eeu. Dit is 'n proses waarin elke herinnering aan die ewige dinge vervaag en die aardse lewe geheel en al einddoel geword het. ${ }^{1}$ ) Hierdie soort lewenslouding, waarin geen plek gelaat word vir God, sy kerk, sy Woord, of vir hoër geestelike waardes nie, noem ons liewer nie sekularisasie nie, maar sekularisme. Sekularisme is dus kortliks te beskryf as die emansipasie van die mens van sy betrokkenheid op die bo-kosmiese.

Hierdie sekularisme plaas die kerk van ons eeu voor een van die moeilikste probleme waarmee dit nog ooit te doen gehad het. Brillenburg Wurth sê selfs dat as die kerk nie by magte is om die proses te stuit nie, dan staan die geestelike ondergang van ons beskawing onherroeplik vas. ${ }^{2}$ )

Nog beklemmender is die feit dat die stellingname van die kerk op aarde teenoor hierdie sekularisme tans geen eenvormige beeld vertoon nie. Daar is natuurlik enersyds 'n sterk krities-afwysende standpunt, soos 'n mens sou verwag, omdat sekularisme in wese antiteties staan teenoor die Woord van God en die God van die Woord, maar daar is andersyds helaas ook waardering: daar is sommige wat sekularisme beskou as 'n positivum. Hier wys ons veral op Dietrich Bonhoeffer. Weliswaar gebruik hy nie die woord sekularisme nie, maar in feite skryf hy oor een en dieselfde saak en gelruik hy slegs ander terminologic. Hy gee 'n skerp tydsdiagnose deur aan te toon dat die beweging wat ongeveer in die dertiende ceu begin voer het in die rigting van menslike outonomie, tans in ' $n$ sekere sin voltooi is. Die mens het geleer om alle beslissinge te neem sonder die ,werkhipotese: God". By wetenskaplike, artistieke en ctiese vrae is hierdie houding reeds geheel en al vanselfsprekend. Maar gedurende die afgelope eeu het dit ook steeds meer die geval geword ten opsigte van religieuse sake. Daar kan nou gepraat word van 'n „mundige Welt". Bonhoeffer sê verder dat die tyd van die religie. d.w.s. 
van die innerlike lewe en die gewete, verby is. Ons gaan 'n volkome religielose tyd tegemoet. Die mens het geleer om alles te behartig ,etsi Deus non daretur". Die Christelike apologetiek probeer nog wel om aan die tans mondiggeworde wêreld te bewys dat dit sonder die voog "God" nie kan klaarkom nie. Ten aansien van wêreldlike vraagstukke het die apologete reeds gekapituleer, maar daar is die sogenaamde "laaste vrae" van dood en skuld, en daarvoor het die mens wel God, die kerk en die predikant nodig. Bonhoeffer vra dan: as die mense met die "laaste vrae" ook sonder God, kerk en predikant kan klaarspeel, wat dan? Ten slotte doen hy 'n dringende beroep op ons dat ons die mondigheid van die wêreld en van die mens moet erken, dat ons die ,Entsakralisierung des Lebens" moet waardeer en op wêreldse wyse, sonder religie dus, Christen moet wees. Daarom het die kerk ook nodig om die bekering, geloof, regverdiging, wedergeboorte en heiliging ,weltlich" „umzuinterpretieren". ${ }^{3}$ )

\section{Die solidariteitsdenke.}

Enigsins breed het ek stilgestaan by die beskouinge van Bonhoeffer omdat daarin ongetwyfeld een van die wortels gesoek moet word vir die sterk beklemtoning van die solidariteitsgedagte in sommige kerklike kringe.

As bv. die Nederlandse Hervormde Kerk in 'n offisiële skrywe van die Sinode oproep tot solidariteit tussen kerk en wêreld, dan is die motivering dat daar in vergelyking met die negentiende eeu 'n radikalc ommekeer gekom het wat sentreer in die ,mondige mens". Die ommekeer is per slot van rekening nie sonder belofte of seën nie. Dit lê in elk geval aan die kerk en die Christen die verantwoordelikheid en die taak op om met dié mens solidariteit te beoefen.

Kenmerkend by sommige van hierdie gedagterigtings is die erkenning van en die positiewe waardering vir sekularisme. Dit moet toegegee word dat dit geheel en al nie vreemd of onverantwoord is dat die kerk 'n onbenewelde visie moet hê op die tydsgewrig nie. Dit bring mee dat die huidige tydsgewrig onderken word as die tyd van die voltooiing van die sekularisasieproses in die negatiewe $\sin$ van die woord. Die uitgangspunt in die standpunt is egter die veronderstelling dat die mens wat prooi van die sekularisne geword het nie meer langs dic gewone weg deur die kerk bereik kan word nic. Daarom word die solidariteit tussen kerk en wêreld in hierdie situasie aangeprys as die enigste redmiddel. ${ }^{4}$ ) Sterker nog: dit word voorgestel asof sckularisme eintlik 'n deur God gegewe geleenthe id is om die ,mondige mens" met die Fvangelic te hereik. Op die vectspoor van Bonhoeffer word sekularisme as 'n positivum beskou. ${ }^{5}$ ) 
Om die solidariteitsdenke soos dit vandag in Nederland te vinde is, goed te verstaan, moet ek die opvattinge van enkele vooraanstaande figure in die kringe aan $u$ voorhou.

As (.. J. Dippel die kerk oproep tot Christelike solidariteit met die volk, dan doen hy dit uit 'n intense besef van die nood van die tyd. Hy meen dat grenselose watasin, ellende en leegheid ons tegemoet snel, as ons rustig en selfversekerd op die ou paaie bly voortwandel. Daar moet 'n aoj) oon wees vir die massa wat, in deze leegheid hulpeloos rondklossen in haar vergeefsche pogingen om het leven te leeren kennen en te leven".6) Daarom meen hy dat elke Christen geroep is tot volkome Christelike solidariteit met die volk. Hy beroep hom op Barth wat sê dat die uitoefening van helpende solidariteit in die uitwendige lewensnood van die samelewing 'n wesenlike funksie van die kerk is. Dit behoort tot "die antwoord van die mense aan God". Ons mag nie op een hoop gaan staan en met vermanende vingers stigtelike woorde rondstrooi nie. Die Woord moet gebring, inderdaad gebring word deur mense wat hulle in niks ten aansien van die skuldvraag onderskei nie. Die gemeente moet werklik glo aan die solidariteit in skuld en moet gedryf word tot die meedra van die skuld van andere. Christus het niks anders gedoen as om die skuld van ander te dra nie. Die hele Bylel spreek van hierdie solidariteit, hierdie verhondenheid met die volk, ook die ongehoorsame volk. Liewer as om 'n seun van Farao se dogter genoem te word, wou Moses met die volk van God solidêr in vernedering verkeer. Jesaja het ook uitgeroep dat hy midde in 'n volk woon wat onrein van lippe is. „Geen oogenblik een afstand nemen van het onreine volk. Dát is christelijke solidariteit".7)

Dit is opvallend dat daar in die vertolking van die gedagte van solidariteit in skuld meermale verwys word na die vernedering van Christus. C. Malders betoog ook wanneer hy die hele saak behandel, dat ons moet leer insien ,dat Zijn (Christus') solidariteit met de wereld niet minder betekende dan op een bepaalde wijze, radicaal en zonder terug. houding, ondergaan en sterven. Een dienstknecht is niet meer dan zijn heer. Wanneer wij ons autonome, theologische, sociale, morele leven (en dat betekent ook levensvormen) niet willen verliezen om Zijnentwil, dan zullen wij het niet vinden".8)

$\Lambda$ s ons luister na wat Hoekendijk oor hierdie kardinale aspek van die solidariteit sê, dan blyk dit dat ook hy die solidariteit van Christus met die wêreld sentraal stel. Hy betoog dat dit in die apostolaat eintlik gaan om 'n oortuigende demonstrasie van die solidariteit van Christus met die wêreld. Hierdie uitgangspunt lei Hoekendijk tot verreikende konsekwensies aangaande die beoefening van solidariteit. Ter wille van 
perspektief op hierdie konsekwensies, word enkele van sy gedagtes oor die besondere tyd wat ons beleef uiteengesit. ${ }^{9}$ )

As die ,advent van die vierde mens" karakteriscer hy die tyd onder andere as ,post-kerkelijk". Daarmee bedoel hy dat die mense buite die kerk die kerk geensins meer verstaan nie. Die buitestaander hou 'n verwronge beeld van die kerk daarop na asof hy alles wat in die kerk plaasvind, sien deur 'n glas wat so geslyp is dat dit die beeld misvorm. Maar ook vanuit die kerk word die „huitestaander" vertékend gesien. So is die terreine binne en buite die kerk eintlik twee wêrelde wat elk 'n monoloog voer. Elkeen praat, maar hulle praat nie met die ander een nie. Vir die besef van die vierde mens is die kerk so volkome met die kultuur van die derde mens geïdentifiseer, dat hy al die kerklike gewerskaf beskou as iets waarmee hy niks te maak het nie en wat nie tot hom gerig is nie. Die kerk is vir hom nog net 'n museum. Om die mens in die wêreld te bereik, so betoog Hoekendijk verder, sal nie meer gebruik gemaak kan word van "beroeps-kerkmense" in die beoefening van die ,apostolaat” nie. Die organe van die „apostolaat" sal hulle sover moontlik moet distansieer van alles wat maar „kerklik" lyk. Alles wat in die werk 'n kerklike stempel dra, moet dus weg, aangesien dit misverstand verwek en as „propaganda" beskou word. So konkludeer Hoekendijk met beklemtoning van die solidariteit: „Dit misverstand kan niet worden weggepráát, het zal weggelééfd moeten worden. Waar het in het apostolaat gaat om een overtuigende demonstratie van Christus' solidariteit met de wereld, zal men duidelijk in deze wereld, solidair met haar, aanwezig moeten zijn. Niet zo af en toe bij een sortie uit de kerkelijke enclave om dan gauw! gauw! weer terug te snellen, maar hlijvend, omdat men weet dat men als christen in de wereld en niet in de kerk zijn Sitz im Leben heeft, als "kind van het Koninkrijk”, dat op de akker der wereld is uitgezaaid."

Hoekendijk verwyt die kerk dat hy dikwels so „onwerelds, vroom en preuts" te werk gegaan het. Vir elke wêreldlike gebaar moes onmiddellik 'n vroom ekskuus gevind word, vir elke teken van solidariteit was daar 'n godsdienstige bybedoeling.

Hoekendijk beweer dat daar voortdurend op die tone deur die wêreld gesluip is met ' $n$ onrustige gewete, terwyl gemaak is asof al die heilsgebeure alleen maar in die instituut van die kerk voltrek word en asof mens dus uit die wêreld daarheen mocs emigreer om behou te word. Hy wil hê die kerk moet op die regte wyse ,wêrclds" wees. Werkdik „wêrelds" kan egter slegs die "leke" wees. Hulle kan in die alledaagse lewe iets demonstreer van die solidariteit van Christus met die wêreld. Daarom ,zal men zich waarschijnlijk voorlopig bewust van de „kerkelijke” sfeer moeten distanciëren." Hy verwys dan na die metode wat al in ver- 
skeic lande gevolg is dat predikante 'n ,wereldlijke" beroep gaan uitoefen het. Ten slotte meen hy dat die kerk pas dan oortuigend die solidariteit van Christus met die wêreld kan demonstreer as dit totaal gebeur, m.a.w. as elke aspek van die kerklike lewe iets gaan toon van ,die gesindheid wat in Christus Jesus was... wat Homself ontledig het en die gestalte van 'in dienskneg aangeneem het en in die gelykenis van mense gekom het."

Om duidelik te hegryp wat met solidariteit bedoel word, word nog geluister na wat G. van der Leeuw sê. Hy heskryf die kerk as 'n sending. kerk wat midde in die wêreld staan met oop deure waarhy die mense die hele dag in en uit kan loop. Die Christen moet met sy geloof ,midden onder het volk gaan staan en aan alles meedoen wat het volk beweegt. Het conserveeren door afzondering van het geloof der kerkleden is eigenlijk een sauveeren dat in den regel niet helpt maar bovenal in strijd komt met de eigenlijke roeping van den Christen op aarde... Wij moeten als Christenen midden in de wereld springen, daar waar het hart van de wereld klopt, waar gedanst wordt of een film gedraaid. En de risico's moeten wij maar nemen; wanneer ons geloof er niet tegen kan, dan beteekent het niet veel".10)

Dit is duidelik dat daar in die solidariteitsdenke nog geworstel word om tot helderheid te kom. Daar is sterk variasie waar te neem in die draagwydte van die begrip en veral in die konsekwensies wat getrek word uit die toepassing daarvan. Maar daar is tog ' $n$ ooreenstemming van gedagtes ten opsigte van die essensie. Solidariteit word deur die meeste van genoemde vertolkers beskou as 'n wesenlike verbondenheid van kerk en wêreld, Christen en nie-Christen, vanweë gemeenskaplike skuld en sonde. Volgens die vertolkers plaas dit dan op die kerk en die Christen die verantwoordelikheid om getuienis te lewer van die solidariteit van Christus met die wêreld. Daarby word van die kerk en die Christen die offer gevra om vir die wêreld "wêrelds" te word en sodoende die Woord van genade te laat hoor.

Die onderskeid tussen kerk en wêreld is alleen daarin geleë dat die gemeente de facto is wat de iure ook vir die wëreld geld. Dit kom daarop neer dat daar eintlik van geen onderskeid tussen mense gespreek mag word nie. Die verbondenheid in verlorenheid vir almal het sy keersy in dic verbondenheid in verlossing vir almal. Die enigste onderskeid is dat die gemeente en die Christene van die genade van God en die verlossing weet, terwyl die wêreld nog nie daarvan weet nie.

Vanuit hierdie basiese veronderstelling is dit duidelik dat die antitese skerp afgewys word. Die praktiese konsekwensie van die solidariteitsdenke is dat die kerk en die Christene opgeroep word om nie ,,separatisties" te werk te gaan nie. Daar moet 'n apostoliese aanvalshouding wees in plaas van ' $\mathrm{n}$ isolerende verdedigingshouding. Geen afsondering dus 
van lidmate van die kerk in aparte skoolaksie, politieke aksie, persaksie, vryetydshesteding, ens., nie, want daardeur sou die Christene apart te staan kom en die solidariteit met die volk verbreek, die Christelike diens aan die wêreld verswak en die buitekerklike deel van die volk geheel en al aan homself oorlaat. Dit sou alleen ontkerstening fluks laat voortwoeker. In die trant redeneer C. J. Dippel as hy die solidariteit aanprys.

\section{Die antitesebeginsel.}

Dit is bekend dat die antitesegedagte 'n belangrike rol gespeel het en nog speel in die Calvinistiese lewens- en wêreldbeskouing, veral in Nederland. Tog moct beklemtoon word dat die antitese geen vooropgestelde beginsel of ' $n$ uitgangspunt in die Calvinistiese lewens- en wêreldbeskouing vorm nie.

Die antitese is veeleer ' $n$ min of meer latente gegewe, wat aktueel word wanneer die gelowige of die kerk in die wêreld optree en die praktyk die aksentuering van die antitese noodsaak.

Dat Kuyper en sy medestanders in die vorige eeu gekom het tot die toepassing en die beklemtoning van die antitese op velerlei gebied, was die uitvloeisel van 'n noodsituasie. Hulle is daartoe gedwing. Die oprigting van afsonderlike skole en die totstandbrenging van Christelike organisasies was in die wese van die saak die noodsaaklike verweer, die „moet" van die heilige roeping om die eer van God en die koningskap van Cliristus aan te kondig teenoor die opdringende en selfs uittartende modernisme.

Kuyper kan wel deeglik beskou word as die man van die felle, diepinsnyende antitese. Hierdie antitese was egter nie voor alles van volksgroepe nie, maar wel van sonde en genade, van ou en nuwe mens, van afgodery in watter vorm ook al en troue diens aan die Here, van die koninkryk van Satan en die koninkryk van God. Dit is die antitese wat 'n nooit eindigende, steeds feller wordende stryd in die wêreld veroorsaak. ${ }^{2}$ )

En tog, hoewel Kuyper die man was van die antitese, moet duidelik gekonstateer word dat Kuyper nie die antitese uitgevind of selfs geproklameer het nie. Kuyper en sy medestanders het die bestaan van die antitese gekonstateer. Daar is immers geloof en ongeloof, daar is gehoorsaamheid en ongehoorsaamheid aan Gods Woord. Christus Jesus is daar tot 'n val en 'n opstanding vir baie. Dooyeweerd stel dit suiwer: die antitese is nie 'n skeidsregter wat 'n Christelike teenoor 'n anti-Christelike volksdeel plaas nie. Dit is die onversoenlike stryd tussen twee geestelike beginsels wat deur die hele volk, ja, deur die hele mensheid heensny, en wat geen kader van Christelike lewensvorme eerbiedig nie. ${ }^{13}$ )

Belangrik is die antitesebeginsel by die oprigting van Christelike 
organisasies. Ons sou kon spreek van organisatoriese antitese. Die kernvraag is: Wanneer word dit noodsaaklik? Hierop kan ons soos volg antwoord: Wanneer die proses van sekularisme intree sodat dit op die verskillende terreine van die samelewing vir die Christen nie meer moontlik is om sy Christenskap te beleef nie, bv. wanneer die Bybel uit die skool verdwyn en wanneer die gees van die rewolusie hom van die politiek meester maak, dan ontstaan daar 'n behoefte aan en selfs die noodsaak vir die oprigting van Christelike organisasies. Die antitese word dan werklikheid.

Die ontstaan van die Christelike organisasies moet dus basies beskou word as die gevolg van die noodsaak van die onontwykbare antitese teen die „onchristelike". Dit gaan in wese om die teenstelling tussen die ryk van die lig en die ryk van die duisternis. Augustinus het geleer dat die geskiedenis die terrein is waar die stryd van die ryk van God met die ryk van die wêreld uitgestry word, en waar die ryk van God voortstu na sy voltooiing. Elke Christelike lewensopenbaring is by hierdie stryd betrokke, en die Christelike organisasie ontleen in eerste instansie sy bestaansreg an die plek wat hy inneem in die stryd tussen die ryk van God en die ryk van die wêreld..$^{14}$ )

Dit is duidelik dat die stryd tussen waarheid en leuen, lig en duisternis, goed en kwaad, nie sigbaar is op alle lewensterreine nie. In gevalle waar nie sighaar stryd is nie, hoef daar geen sprake te wees van prinsipiële organisasies nie. Dit wil nie sê dat prinsipiële antitese nic oral en altyd in hierdie bedeling bestaan nie. Inteendeel, prinsipieel is die antitese daar maar die organisatoriese positivering daarvan is nie altyd ewe noodsaaklik nie. Die noodsaak ontstaan daar waar die vooruitgang van die koninkryk van Christus en die positiewe deurwerking van die Evangelie verhinder of gestrem word. So het dit op die gebied van die onderwys in die vorige eeu in Nederland gebeur dat die Bybel uit die skool verban is en dat die onderwys te staan gekom het in diens van 'n Christendom bo geloofsverdeeldheid. Daar moes toe gestry word om die reg van Christelike onderwys. Vrye Christelike skole is in die lewe geroep op inisiatief van georganiseerde, enersdenkende Christelike ouers. Hierdeur het die antitese op onderwysgebied sy beslag gekry. Die antitese is nie gesoek nie, dit was prinsipicel aanwesig. Die nood van die tyd het dit in die optrede van die Christusgelowiges laat gestalte aanneem.

\section{Kritiese bespreking van solidariteit en antitese.}

Die eerste en belangrikste punt van kritiek teen die sterk aksentuering van die solidariteitsgedagte soos ons dit vandag allerweë vind is dat dit ongetwyfeld voer tot verwêreldliking van die kerk. Prinsipieel gesien is dit onjuis om din verhouding van kerk en wêreld te bepaal vanuit 
die eietydsinterpretasie, want sodoende stel mens jou bloot aan die gevaar van situasionisme. Vanuit die historiese gang in die volkslewe en die nood van die wêreld word die posisie van die kerk bepaal. Die skuldsolidariteit van kerk en wêreld moet dan prinsipieel die verhouding van kerk tot wêreld motiveer. En as die prinsipiële antitese tussen die ryk van die lig en die ryk van die duisternis uit die oog verloor word, lei dit prakties tot onhoudbaarhede. On maar een te noem: Die positiewe waardering van die sekularisme waardeur die solidariteitsdenke gestut word, bring mee dat van die kerk en die Christen verwag word om self "wêrelds" te word. Die Christen moet bv. in die radikaalste sin naas die moderne of gesekulariseerde mens optree. Die solidariteit in skuld en sonde moet elke verskil en afstand nivelleer. Die Christen kan en moet, met al die risiko's wat daaraan verhonde is vir sy geloof, meedoen aan die wêreldse dinge. Die solidariteit met die sondaar kan so verloop in 'n solidariteit met die sonde. Wat dán nog oorbly van die "Christelike" in die solidariteit is ' $n$ ope vraag.

Daarmee word die verwêreldliking van die kerk sterk in die hand gewerk. Maar daar is nog 'n ander kant van die saak wat byna in paradoksale verhouding staan teenoor die tendens wat so pas genoem is.

Die sterk beklemtoning van die solidariteit van die kerk met die wêreld lei tot verkerkliking van alle terreine buite die kerkinstituut. Uitgaande van die standpunt dat die kerk die prerogatief besit oor die gebruik van die Woord van God, en die lig van die Woord alleen daar kan val waar die kerk dit laat skyn, voer die solidariteitsdenke onwillekeurig tot klerikalisering van die werklikheid.

Daar is dus dié eienaardige dialektiese spanning aan te wys in die „doorbraak"-denke: aan die een kant profanisering van dic werklikheid in al sy fasette buite die kerkinstituut, aan die ander kant klerikalisering van dieselfde werklikheid. Die dialektiese spanning word veroorsaak deur niks anders as die sintesedenke wat anhaak by die Thomisme van die Middeleeue nie. Deur heeltemal die rug te draai op die anti-sintetiese instelling van die Reformatoriese denke, het die „doorbraak"-standpunt weer gevoer tot 'n valse skeiding en daarna 'n valse sintese tussen kerk en wêreld, 'n sogenaamde terrein van die genade en terrein van die natuur.

Teen die sterk aksentuering van die antitese, veral op organisatoriese gelied, word daar ook skerp kritiek ingebring. Die kritiek is nie in alle opsigte ontbloot van die waarheid nie. Ek noem alleen die sogenaamde verwyt van ,vereenselwiging".

Hierdie aspek van die kritiek is basies teen die uitgespı oke Christelike karakter van die organisasies en teen die pretensic wat die organisasies daarop nahou dat hulle oor sekere Christelike leginsels beskik wat 
altyd geldend is en wat onder alle omstandighede in toepassing gebring moet word. In die kritiek word besonder sterk standpunt ingeneem teen die "beginselprogramme” en Christelike „,hewussynsinhoude” waarvan sprake is by die Christelike organisasie. Die euwel van vereenselwiging beteken die vereenselwiging van bepaalde "Christelike" beginsels met die Evangelie, of selfs die vereenselwiging van 'n bepaalde "Christelike" lowenshouding met die gehoorsaamheid aan Christus.

Daar is dus die gevaar dat Christene bepaalde beginsels of beginselprogramme van sosiale, ekonomiese of politieke aangeleenthede kan verabsoluteer. Daar is die gevaar dat van 'n persoonlike of kollektiewe opinie 'n beginsel gemaak kan word. Daar is die gevaar van ydele roem in organisatoriese prestasies onder Christelike vaandel.

Maar selfs die erkenning van al die gevare van sulke ontsporinge in die praktyk mag nie lei tot dubieusstelling van die bestaan van die Christelike organisasie nie. Dit mag nie lei tot 'n relativering van die hestaansreg van beginsels as sodanig nie. Erkenning van die gevaar van absolutisme mag nie tot relativisme voer nie. Dit mag ook nie lei tot die konstatering van 'n teëstelling tussen die Christelike persoonlikheid en Christelike beginsels, tussen lewe en leer, wandel en belydenis, ' $n$ „zijnswijze" en 'n „denkwijze" nie.

Christus en sy koninkryk as Archimedespunt vir die bepaling van die verhouding van kerk tot wêreld.

Jesus Christus, wat Hoof is van die kerk en Koning is oor die wêreld, moet as uitgangspunt in ons denke geneem word vir die suiwere bepaling van die verhouding tussen kerk en wêreld.

Deur sy arbeid het Christus vir Hom 'n gemeente vergader, maar deur sy arbeid ontvang $\mathrm{Hy}$ ook alle mag in die hemel en op die aarde. Hy is Koning oor die wêreld en Hy is Hoof van sy gemeente.

Christus se heerskappy oor hierdie wêreld is 'n realiteit: aan Hom is alle mag gegee. Tog het die volkomenheid van sy ryk nog nie gekom nie; die stryd wat in beginsel op Golgota besleg is, duur nog. Ons leef tans in die verwagting van dic komende koninkryk. Alles op hierdie aarde moet gesien word met betrekking tot die voortstuwende gang van sy koninkryk. Die gelowige en die kerk sien uit na die parousie, wanneer $\mathrm{Hy}$ die Koninkryk aan God die Vader oorgee, as $\mathrm{Hy}$ alle heerskappy en alle gesag en alle mag vernietig het. Want $\mathrm{Hy}$ moet as Koning heers totdat $\mathrm{Hy}$ al sy vyande onder sy voete gestel het (I Kor. $1: 24,25$ ).

$\Lambda$ s uitgangspunt van die verhouding tussen kerk en wêreld wil ek dus nóg antitese nóg solidariteit stel maar die positiewe verhouding tot Christus. Die liefdesgebod wat sowel 'n positiewe as 'n negatiewe inslag het, is bepalend. 
Die kerk en die gelowige moet in die wêreld getuienis lewer van die liefde van Christus. Die vergestalting van die liefde is die kruis van Jesus Christus en dit is wat die gelowige en die kerk dus verkondig. Wie kruis sê, sê egter behalwe versoening ook skeiding, behalwe solida. riteit ook antitese. By die kruis van Christus word hart aan hart verbind maar by die kruis gaan ook weë uitmekaar. Christus is 'n val en 'n opstanding. Hy het gekom om vuur op die aarde te werp en ook om verdeeldheid te loring. Die liefde van Christus het dus nie alleen 'n behoudende krag nie, maar ook 'n keersy. Liefde kan ook oordeel, afwys, toorn. As die Skrif spreek van God is liefde en God is 'n verterende vuur, hevat die twee uitsprake geen kontradiksie nie. Die kruis is daarvan die bewys.

Sowel die gelowige wat geroep is tot navolging van Christus as dic gemeente wat in die wêreld gestel is tot "n getuienis van die liefde van Christus, staan prinsipieel nie alleen in die verhouding van naasteliefde tot die wêreld nie maar ook in die verhouding van antitese, van stryd. 1)ie struktuur van die liefde bevat dus ook ' $n$ antitetiese clement. Die liefdesgebod wat my voor die opdrag stel om my naaste soos myself lief te hê vir sover ons die trekke vertonn van onse Vader in Christus, stel my tegelykertyd voor die opdrag om sowel my naaste as myself te haat, vir sover daar by ons die teenoorgestelde trekke tot openbaring kom. Net soos die liefde tot God en die liefde tot die naaste vir die gelowige in Christus prinsipiële werklikheid geword het, so is ook die antitese teen alles wat die karakter van die sonde en die ongehoorsaamleid teen God vertoon. Sou ek diẻ nie hat wat vir $U$ haat nie? (Ps. 139:21). Die positivering van die antitese kan, sodra die gelowige of die kerk in die wêreld optree, ook nie uitlly nie. Jesus sê duidelik: Maar omdat julle nie van die wêreld is nie, maar Ek julle uit die wêreld uitverkies het, daarom haat die wêreld julle. Onthou die woord wat Ek vir julle gesê het: 'n Dienskneg is nie groter as sy heer nic. As luulle My vervolg liet, sal hulle jul ook vervolg (Joh. $15: 19,20)$.

Duidelik is dit dat die wêreld op tweërlei wysc bejeën kan en moet word.

Die wêreld is aan die een kant dic van God geëmansipeerde wêreld. Daarin is die kerk en die gelowige uiteraard 'n vreemdeling. Die wêreld ken nie die kinders van God nie omdat dit Hom nie ken nie. Daarom haat die wêreld die gelowiges. Aan die ander kant is dieselfde wêreld die voorwerp van God se liefde. Daarvan sê Paulus dat God in Christus die wêreld met Homself versoen het. Ondanks die wêreld sc afval van God, en die daaruit gehore vyandskap teen sy kerk, bly die wêreld Gods wêreld, en as sodanig die tonecl van sy heilshistoriese arbeid. Daarom mag die kerk en die gelowige hul nie van die wêreld distansieer nie: 
hul roeping lê dáár. Vir sover die wêreld in vyandskap teen God leef, is alle vriendskap met die wêreld veroordeel. Maar vir sover God nog in liefde die wêreld soek, het die kerk die taak om dit met liefde te bejeën en dit op te eis vir God en Christus.

Daar moet dus onderskei word tussen 'n liefde tot die wêreld ter wille van die wêreld en 'n liefde tot die wêreld om Christus ontwil.

"In die wêreld" maar ,nie van die wêreld nie".

Die twee houdinge van begrensdheid en openheid is prinsipieel altyd aan die gemeente en aan die gelowige eie. Die een gaan nie voor die ander nie, daar is geen polêre situasie nie. Albei is gegee in die navolging van Christus. Dit is 'n spanningvolle wêreldverhouding wat die gelowige en die kerk om Christus ontwil nooit mag ontvlug nie; dit is die verhouding waarmee altyd erns gemaak moet word. Dit hou sowel 'n ja as 'n nee jeens die wêreld in.

Die kerk het dus jeens die wêreld 'n duidelike bestemming wat sowel die nee as die ja insluit, of wat in die woorde van Jol. 17 sowel die ,uit die wêreld" as die ,in die wêreld" omvat. Ooraksentuering van een aspek ten koste van die ander tas die bestemming aan. Die ware bestem. ming word angetas wanneer die kerk hom uit die wereld onttrek in die sin van distansieer, maar ook wanneer hy in die wêreld opgaan en hom daarin tuis voel.

Die wêreld is nooit 'n neutrale terrein nie. Dit is sowel manifestasieonrd van die mag van Satan as die voorwerp van Gods liefdevolle bemoeienis. In soverre die mag van Satan in die wêreld tot openbaring kom, moet die kerk in skerp antitese sy nee uitroep; in soverre die liefdeswerke van God egter daarin ruimte moet vind en in soverre dit as 'n instrument dien in die voortgang van die koninkryk van God, moet die kerk jeens die wêreld ja sê -. om Christus ontwil. Dan staan die ja in die teken van Kol. 3 : 23: „En wat julle ook al doen, doen dit van harte soos vir die Here en nie vir mense nie."

Potchefstroom.

S. C. W. Duvenage.

1) R. Schippers: De Gereforneerde Zede, Kampen, 1954, p. 183

2) G. Brillenburg Wurth: „Het aposlolaat van de Kerk" in dezen tijd, De a postolische Kerk, Kampen, 1954, p. 100.

3) Dietrich Bonhocffer: Widerstand und Ergebung, München, 1951.

Veral p. $178-184,215-22], 238-242,257-261$.

4) A. de Kleine: Evangelie zonder Kerk?, In de Waagschaal, 7 Maart 1947, p. 2.

5) Vgl. H. Kraemer: Communicatie, een tijdvraag, 's-Gravenhage, 1957, p. 129; J. de Graaf: Kerugna en Communicalic, Nederlands Theologisch tijdschrift, 1958 1959, p. 213; G. C. van Niftrik: De boodschap van Sartre, Nijkerk, 1953, p. $148,149$.

6) (.. J. Dippel: Kerk en wereld in de crisis, 's-Gravenhage, 1948, p. 90. 
7) C. J. Dippel: a.w., p. 91 .

8) C. Aalders: Crisis der vormen, Evangelische benadering van de mens, Delft, 1951, p. 47.

9) J. C. Hoekendijk: Rondon het apostolaat, Wending, 1952-1953, p. 557 vv.

10) G, van der Lceuw: Kerk en volk, Wending, 1946-1917, p. 8.5.

11) C. J. Dippel: a.w., p. 181 v.

12) C. Veenhof: Soevereiniteit in eigen kring, Kampen, 1939, p. T.t.

13) II. Dooyeweerd: Vernicuwing en Bezinning om het reformatorisch grondmotief, Zutphen, 1959, p. 3 .

14) S. U. Zuidema: Het Getuigenis onzer Christelijke Organisalic, Onzc Banier, 15 Aug 1950, p. 139.

15) Vgl. II. Thielicke: Theologische Ethik, II, J, Tübingen, 1959, p. 46 v.; A. de Quervain: Kirche, Volk und Staat, Ethik II, Zollikon-Zürich, 1915, p. 26; G. Brillenburg Wurth: Kerk en wereld, Christelijke Fncyclopedie 1, p. 217. 